\title{
FOR COLUMBUS
}

\author{
Cyril Dabydeen
}

\begin{abstract}
I
When grapes are her breasts

And apples her skin, I am at home-

I long for Italian brothers, Greek sisters,

An African father
\end{abstract}

an Indian mother.

I long with the same longing

As the clouds coming down, the sky

About to tilt over

Like a ship in a hefty sea.

I also long for a French aunt

Who will elegantly raise her a handkerchief

In the wind, signalling an archipelago--

As I cry out, "Islands, islands!"

\section{II}

Now it is you who I remember,

Your neck bruised, the shadow

Of an axe coming downing

in the Tower.

You too Cortez, as Montezuma burns

Inside, his cry resounding in the night;

You with your Quetzalcoatl face,

Cultural and Pedagogical Inquiry, 2016, 8(1), pp. 8-9

ISSN 1916-3460 (c) 2016 University of Alberta

http://ejournals.library.ualberta.ca/index.php/cpi/index 
A helmet still glinting.

Pizarro next,

And I watch the Incas in silver mines

Living out a life, buried in sand, their heads

Above the ground while the ocean once more

threatens disaster.

\section{III}

With a Crusoe mask, I listen in the distance,

Our Friday's commands,

The Spanish Empire sinking in the background--

This treasure being all I am left with,

Bible in hand, the sun whipping by,

A lopsided moon sinking lower

into the bottomless sea,

As I try to jump over it, my paradiso,

El Dorado, the heathen sky

Falls prostrate

at my feet.

Cultural and Pedagogical Inquiry, 2016, 8(1), pp. 8-9

ISSN 1916-3460 (C) 2016 University of Alberta

http://ejournals.library.ualberta.ca/index.php/cpi/index 